British Journal of Chinese Studies, Vol. 11, July 2021

ISSN 2048-0601

(C) British Association for Chinese Studies

\title{
Branding the Chinese Dream: Reception of China's Public Diplomacy in Britain’s "Cultural China”
}

Yan Wu, Sian Rees, Richard Thomas, and Yakun Yu

Swansea University

\begin{abstract}
Over four decades, China's transformed propaganda system has embraced public diplomacy to dispel its perceived "threat." The most recent strategy has been the branding of the Chinese Dream narrative. Although there has been some academic focus on China's nation branding, little has been written about its reception by overseas audiences. Accordingly, this article draws on focus-group data and employs Tu Wei-ming's "cultural China" framework in exploring how the Chinese Dream is received and interpreted in the United Kingdom. This article contributes to understandings of nation branding by recognising how Chinese diaspora communities and British intellectual and professional elites engage with and promote brand values. It argues that the socio-cultural aspect of branding is important for China's identity and that using the Chinese Dream as a branding narrative is successful when it focuses on cultural and economic messaging but divides opinion when political ideology is used.
\end{abstract}

Keywords: Cultural China, Chinese Dream, public diplomacy, nation branding, cultural congruency, soft power communication

\section{Introduction}

This article examines the reception of China's changing public diplomacy within the framework of "cultural China” (Tu 1994 [1991]), using the recent Chinese Dream (Zhongguo meng 中国梦) nation-branding campaign as a case study. With its increasing economic, political, and military strength, China has been perceived as an exemplary model of progress by some developing countries, but also as a challenge to the interests of the United States, Asia-Pacific security, and human rights worldwide. In combating the "China threat" discourse, the Chinese Dream has been used as a discursive power strategy in mediating China's rise in the global community in recent years. Whilst there is a growing body of literature on China's use of soft power (see Li, 2009, among others), there is limited scholarship evaluating China's nation-branding activities, and the subsequent reaction of various audiences (He et al., 2020). This article aims to bridge the gap in the current literature by analysing data from focus groups conducted in the United Kingdom.

Over the past four decades, China's public diplomacy has aimed to dispel the widespread perception of a "China threat" (Ji and Zhou, 2010). The "harmonious world" proposed by President Hu Jintao in 2004 was China's first attempt to implement Confucianstyle domestic policies, promoting unanimity simultaneous with China's growing global prominence. As Geis and Holt (2009) argue, the Hu Jintao-Wen Jiabao government employed early Chinese philosophy such as Confucianism to promote indirect, low-profile actions. When power was transferred to President Xi Jinping, Chinese foreign policy began to stress China's global standing and called 
for a "new type of great-power relationship" with the US (Calmes and Myers, 2013), maintaining Confucian elements and adopting Western branding practices to build empathy with overseas audiences.

President Xi's key brand slogan is the Chinese Dream. First articulated in 2012, the Chinese Dream discourse reflects Communist Party of China (CPC) initiatives to rebrand its political propaganda as soft-power communication in both domestic and external contexts. Economically, the Chinese Dream aims to sustain China's prosperity while curbing challenges associated with urbanisation, welfare reform, and environmental degradation (Kuhn, 2014). Politically, it aims to "rejuvenate" China into a modern, democratic socialist country that is culturally "advanced" and militarily strong (State Council Information Office of the PRC, 2015). On an individual level, the Chinese Dream promises to improve education, employment, income, social security, medical care, housing, the environment, and personal career development (Kuhn, 2014). Nevertheless, these individual aspirations can only be fulfilled when the Chinese state achieves its global significance. As the state media instructs, "only when the country is doing well, can the nation and people do well” (China Daily, 2014).

Through its emphasis on Confucian cultural values, the Chinese Dream also aims to reach overseas audiences, which include ethnic Chinese populations outside China (often referred to as "overseas Chinese") and "China sympathizers." Both demographics constitute a significant part of "cultural China."

“Cultural China,” according to Tu Wei-ming (1994 [1991]), consists of "three symbolic universes." The first symbolic universe of geographical and political entities consists of mainland China, Taiwan, Hong Kong, and Singapore. The second symbolic universe of global ethnic and cultural communities consists of the Chinese diaspora worldwide. The third symbolic universe of intellectual and linguistic communities consists of intellectual elites whose professional activities contribute to global understanding of and engagement with China. The latter two groups constitute the target audience for China's nation-branding efforts worldwide.

Chinese overseas are highly valued "unofficial ambassadors” (Xi, 2014: 66) in China's public diplomacy campaigns, and Xi has called for the Chinese cultural brand to be endorsed by all its people: "No matter where a Chinese is, they always bear the distinctive brand of the Chinese culture, which is the common heritage of all the sons and daughters of China” (Xi, 2014: 70).The target non-Chinese audience of intellectual communities comprising literary, academic, business, and other elites is addressed in subtle ways in the political rhetoric. Research on Xi's lunar new year speeches ( $\mathrm{Wu}$, Thomas, and $\mathrm{Yu}, 2021$ ), streamed worldwide since 2014, reveals that Xi delivers them to "comrades, friends, ladies and gentlemen." While "comrades" is a popular greeting among CPC members, "friends" indicates a feeling of respect and affection and "ladies and gentlemen" is conventionally used when addressing non-Chinese business, political, and intellectual elites, aiming to reach China sympathisers worldwide.

Examining the reception of this messaging in the complex context of ethnicity, politics, and culture is a necessary element of nation-branding success, but remains underexplored (Gertner, 2011; Hassan and Mahrous, 2019; He et al., 2020). While audiences overseas are clearly an important part of China's public diplomacy campaigns, their impact on and efficacy with these intended audiences is less clear at present. The aim of this study is to address this gap in the current literature and to examine the reception of China's changing public diplomacy in the UK's "cultural China” via the case study of the Chinese Dream nation-branding practice.

The article is structured as follows: In the first part we contextualise the research by reviewing literature on China's changing communication strategies, from external propaganda to branding, as well as offering a critique of the relevance of "cultural China" in the Chinese state's 
public diplomacy. We follow this with an explanation of our research design, the rationale of our data-collection and data-analysis techniques, before presenting our findings based on the thematic analysis of focus-group interview data. The article concludes with a critical evaluation into the effectiveness of the Chinese Dream in soft-power communication, contributing to scholarly debates concerning nation branding in public diplomacy.

\section{From External Propaganda to Branding China}

After establishing the People's Republic of China in 1949, the CPC adopted a Soviet-style propaganda model. State communications activity aimed "to transmit social and political values in the hope of affecting people's thinking, emotions, and thereby behaviour" (Kenez, 1985: 4). Isolated from Western democracies, state communication aimed at a public overseas was categorised as “external propaganda” (duiwai xuanchuan 对外宣传), which adopted a defensive stance involving rebutting unfavourable reports about China, publicising government statements, and improving global awareness of China (CPC Central External Propaganda Research Office, 1998).

After reforms in the late 1970s, the CPC's control of media relaxed as China's creative industries became subject to marketisation, differentiation, and de-ideologisation (Lieberthal, 2004; Lynch, 1999; Yang and Calhoun, 2007; Zhao, 1998). The reduced state control of media, the end of the Cold War, and China's membership in the World Trade Organization and other international organisations had an influence on external propaganda. Furthermore, from the mid1990s the internet created new dynamics among the state, media, and domestic and international publics, and further increased China's capability to modernise its external propaganda and engage with global communities.

In 1983, the Division of Public Diplomacy (now the Office of Public Diplomacy) was established within the Ministry of Foreign Affairs, indicating the CPC's adoption of marketing strategies to address unwanted Chinese stereotypes and negative associations (Loo and Davies, 2006) and to maintain its "all-important name brand," leading to significant changes in "the content and meaning of the Party's activities" (Brady, 2008: 3). The following year, China International Cultural Communication Centre (CICCC) declared itself a cultural bridge between China and the world. Although old methods of ideological control, including censorship by government bodies and voluntary self-censorship practiced by media organisations, are still used, new methods such as political public relations and mass persuasion have become dominant in using the market to set social norms and justify control (Brady, 2008: 3). Various examples of new forms of diplomacy have been recorded in scholarly studies, including the adoption and sophistication of the government spokesperson system (Chen, 2011); China's expanding international media network globally (Zhang, 2021); student and scholarly exchange programs (Polumbaum, 2011); the establishment of the Confucius Institute programme (He et al., 2020); and non-state actors' entanglement with the state’s national interests (Tang and Li, 2011).

China's soft-power work and brand promotion is not unusual in the world; several studies have focused on place branding in recent years (Anholt, 2002; Gertner, 2011; Kavaratzis and Hatch, 2013; Wu, 2016). Nation branding has been conceptualised as key to cultural and political diplomacy (He et al., 2020; Hurn, 2016) and the branding of places and nations is now a specific discipline (Wu, 2016) covering the construction and reconstruction of regional identity (Jones et al., 2009), with the usual aim of targeting foreign stakeholders for tourism and marketing purposes (Merkelsen and Rasmussen, 2016; Hassan and Mahrous, 2019). Politically, nation-branding campaigns use marketing techniques to project the brand equity of a nation (Hurn, 2016) and build positive meanings and associations (Anholt, 2010), but message consistency is often difficult to achieve due to the multidimensional nature of places and stakeholders (Gross et al., 
2009; Kemp et al., 2012). Instead of focusing on propagandistic image reproduction, success in nation branding often depends on relationship building (Wu, 2016) and co-creation between users and influencers (Kavaratzis and Hatch, 2013), in which communications, events, and slogans help to evoke a sense of identity, ownership, and belonging (Barr, 2012). According to Wu (2016), reciprocal commitment is at the heart of these relationships. This mirrors how modern brands are conceived as constructivist amalgamations of different interactive activities, in which actors inside and outside of organisations contribute to real-time brand production and representation (Rees, 2020). Whilst relationship building and trustworthiness in nation branding are often a part of the process of attracting foreign visitors, they are less scrutinised as a tool for soft power and public diplomacy, as is the reception of nation-branding messages (Anholt, 2007). Similarly, nation-states have been reconceptualised as being in flux and deterritorialised, with supra-national cultures existing outside state borders, contributing to the state as a "global-national imaginary" (Yang 2015), so the interpretations and actions of the "cultural China" becomes an important element of nation branding.

Despite the challenges associated with its human rights record (d'Hooghe, 2005; Kurlantzick, 2007; Nye, 2012), China has successfully used place-branding techniques to gain global recognition via soft-power mega-events like the 2008 Beijing Olympics, the promotion of its World Natural Heritage sites (Nakano and Zhu, 2020; Wang and Yuan, 2020), and advertisements and cultural exchanges (Barr, 2012; Cull, 2008; Servaes, 2012). China's cultural values include centuries of heritage, encapsulated, for example, in Confucianism, Taoism, and other aspects of ancient Chinese wisdom (Loo and Davies, 2006). China's soft power resources are often associated with cultural heritage maintained beyond its border in the diaspora experience and cultural-exchange activities, with media globalisation enabling supra-national forms of identity to develop outside state-defined territories (Yang, 2015: 6). Such cultural elements, which include cinema, literature, acupuncture, traditional medicine, cuisine, martial arts, and painting and calligraphy, are popular overseas and help connect the China brand to positive cultural associations (d'Hooghe, 2005). It is possible, therefore, to see how overseas audiences might promote or resist China's nation-brand construction, as part of this interactive global process.

\section{China's Public Diplomacy in Cultural China}

Considering the branding strategies used by China to reach publics overseas, Tu's conceptualisation of cultural China offers a critical framework for this research. In the case of the UK, Tu's second and the third symbolic universes are the target destinations of China's public diplomacy, that is, the Chinese diasporic community and the international community of publics whose professional or personal ties link them closely to the Chinese state.

The 2011 UK census shows that 0.7 percent of the overall population identified themselves as "ethnic Chinese" (ONS, 2013). The number of non-UK-born residents who reported China as their country of birth was 170,000, accounting for 0.27 percent of the overall population (ONS, 2013). Terminologies such as "Chinese diaspora," "Chinese migration," and "Chinese overseas" could mistakenly imply "a monolithic entity," while overlooking the greater diversity of experience (Benton and Gomes, 2011; Miles, 2020). Early immigrants from British colonies in Asia - mainly seamen, peasants, and craftsmen - formed early settlements in London and other major cities, while more recent immigrants from mainland China are mostly studentsturned-highly-skilled-professionals (Benton and Gomes, 2011; Ding, 2007). Differences in countries of origin, migration patterns, history, economic status, and the diaspora institutions belonged to means that the contemporary British Chinese community is neither homogenous nor monolithic (Benton and Gomes, 2011: 10).

Despite the differences within the community, British Chinese in general fare well in terms of education, economics, health, and well-being compared with other ethnic groups in the 
UK, which, to a degree, contributes to the problem of racial discrimination against this demographic. Ethnic Chinese in the UK suffer from different forms of racial discrimination and their experiences of racism often remain unseen or overlooked. Racist abuse ranges from "racism name-calling to damage to property and businesses, arson, physical attacks sometimes involving hospitalisation and murder" (Adamson et al., 2009). Discriminatory practices also create problems and penalties for ethnic Chinese accessing employment outside their enclave economies, including lower rates of pay (Pang, 1996; Mok and Platt, 2020).

The Chinese state has proactively engaged its ethnic overseas communities since reform and opening up in the late 1970s. The CPC has developed five policies to this end since 1978, including "attracting migrant remittances and investment," "launching cultural and educational exchange programs," "establishing government or nongovernment diaspora institutions," "implementing friendly exist/entry laws and regulations," and "developing international broadcasting towards diasporic populations" (Ding, 2015: 233). During the Xi administration, three further policies were adopted to strengthen engagement with ethnic Chinese overseas: "indigenising international communication to improve China's national image; jump-starting immigration reform to win the minds and hearts of overseas Chinese; and strengthening education exchange to shape the diasporic identity of overseas Chinese” (Ding, 2015: 231).

The rapid development of digital media and communications technologies since the 1990s has further transformed China's public diplomacy targeted at ethnic Chinese overseas. From a top-down perspective, foreign policy is now not only conducted officially but also via "a globally accessible media system” (Riley, 2014: 231). In the past three decades, China has encouraged its state-controlled media to "go global" and although they chiefly report global issues from China's perspective (Chang and Lin, 2014), they have also emotionally appealed to ethnic Chinese overseas, emphasising bonds between mainland China and the diaspora, who have been enlisted for nation building and branding (Miles, 2020: 251). Since 1983, China Central Television (CCTV) has connected ethnic Chinese globally at "an annual diasporic moment," celebrating the lunar new year and focusing on mainland China as the "ancestral nation" (zuguo 祖国) (Miles, 2020: 250). Sun Wanning (2006: 12) warns that state-controlled Chinese-language media create new dynamics around the sense of belonging where Chinese migrants are often "positioned uneasily in relation to the nation-building projects of both the country of origin and the destination."

This uneasiness felt by overseas Chinese in the country of destination has been aggravated by the fast-changing digital technologies in recent years. Where the internet has created sophisticated communication networks transcending national boundaries, more actors, including the general public, now enter the realm of public diplomacy to construct their own narratives.

From the bottom up, the use of media, including letters, telephones, videotapes, broadcasting, cinema, and digital media shape the cultural identities of diasporas in their host countries (Dayan, 1998). The "push" factor discourses from the host society (such as racial discrimination, unconscious bias, glass ceilings in career development, etc.) are accompanied with "pull” factors towards "home," creating further tensions between minority and host communities. In the case of the Chinese overseas diaspora, Chinese-language media usage contributes to a "global Chinese village," which impacts on Chinese transnational imagination (Sun, 2002). The use of Chinese-language websites, news groups, online magazines, and web forums offers "a common cultural repertoire” and develops a transnational Chinese cultural sphere (Yang, 2003: 486) or even a "Cyber Greater China" (Wu, 2007). The availability of mobile communication and social media platforms further connects overseas Chinese to home within a multidimensional space where meaning making practice bleeds across public, semi-public, and private spheres (Wu and Wall, 2019b). 
Some researchers (Liu, 2005; Liu and van Dongen, 2016; Nyíri, 1999; Nyíri, 2001) suggest that Beijing has played an increasingly important role in shaping the structure and identity of Chinese overseas. Nyíri (1999: 68), for example, observes "a pan-Chinese identity” projected by new immigrants to Hungary from mainland China, and a form of "deterritorialised nationalism" based on the "official nation-state ideology" (Nyíri, 1999: 122). Hong Liu (2005) observes that new Chinese nationalism overseas revives notions of the country's economic prosperity, cultural regeneration, and national unification.

While it is possible to point to significant literature regarding Chinese diaspora and public diplomacy, there is little research that examines cultural China's "third symbolic universe" (Tu 1994 [1991]) which consists of non-Chinese-language writings and professional activities that shape the global perception of China. Empirical evidence suggests that ties between the UK and China have been strengthened in the past decades. The growing academic interest in China-related studies in the UK, the increased number of scholar and student exchange programs, frequent interactions between British businesses and Chinese businesses constitute a possible "third symbolic universe" of cultural China. In the higher education (HE) sector, there are at least 44 UK universities offering Chinese studies degree programmes and at least 21 UK universities have a Chinese studies research centre, attracting between 1,200 and 1,400 students annually (British Association for Chinese Studies, 2020). Mainland China contributes 12 percent of the overall UK higher education international student body (UK Council for International Student Affairs, 2019). In terms of international student mobility, the number of UK students travelling to China has grown steadily, reaching 2.8 percent of the total number of students studying abroad in 20172018 (Universities UK, 2019). Meanwhile, the UK has been the largest EU investor in China and the bilateral trade in goods and services covers almost every economic sector. The British Chamber of Commerce in China (2020) reports that UK imports from China reached $£ 49$ billion in 2019, and UK exports to China reached $£ 31.4$ billion. Collaborations and interactions between the two nations evidently create professional and personal ties between the two peoples, which opens the possibility of the "third symbolic universe" of cultural China in the UK.

\section{Research Methods}

Building on Tu’s (1994 [1991]) “cultural China” framework, we explore in this article how the Chinese Dream is received and interpreted in the UK. We contribute to understandings of nation branding by recognising how Chinese diaspora communities and British intellectual and professional elites engage with and promote brand values. Drawing from focus group data, we answer the following research questions: How is the Chinese Dream narrative received and interpreted? How are the nation-branding strategies evaluated in relation to changing Chinese identity?

Three focus group interviews were carried out in Wales in March 2018. Participants were selected according to Tu's articulation of the second and third symbolic universes. Five firstgeneration, "new" immigrants from mainland China made up Group A; five ethnic Chinese from other Greater China regions (including Hong Kong, Taiwan, Malaysia, and one second-generation immigrant from the UK) made up Group B, while Group C consisted of five non-Chinese Sinophiles with links to mainland China via professional (past work experience in China and/or current professional links to China) or personal (marriage) ties. All of the Sinophile participants had visited China, and two had lived in China on a short-term basis. Based on the preferences of the participants, the Group A interview was conducted in Mandarin Chinese, the Group B interview was conducted in a mixture of Mandarin Chinese and English, and the Group C interview was conducted in English. Demographic details of the participants are shown in Table 1. 
Table 1. Demographic details of the participants

\begin{tabular}{|l|l|l|}
\hline Gender & Female & Number \\
\hline & Male & 8 \\
\hline Age & $20-29$ & 7 \\
\hline & $30-39$ & 4 \\
\hline & $40-49$ & 6 \\
\hline & $50-59$ & 3 \\
\hline \multicolumn{2}{|l|}{} & 2 \\
\hline Employment status & Employed & 9 \\
\hline & Self-employed & 3 \\
\hline & Other (student/retired/voluntary worker) & 3 \\
\hline Years living in the UK & 6 \\
\hline & $0-10$ & 3 \\
\hline & $10-20$ & 1 \\
\hline & $20-30$ & 5 \\
\hline & Born in the UK & 5 \\
\hline Country or region of origin & 2 \\
\hline & Mainland China & 1 \\
\hline & Hong Kong & 1 \\
\hline & Taiwan & 4 \\
\hline & Malaysian & 1 \\
\hline & UK & 1 \\
\hline & US & 7 \\
\hline & European Union & 8 \\
\hline UK nationality & & \multicolumn{2}{l}{} \\
\hline & UK residents & \\
\hline & UK nationality (including dual nationalities) & 8 \\
\hline
\end{tabular}

Focus group interviews explore "a specific set of issues" and the group is "focused' on some kind "of collective activity" (Kitzinger and Barbour, 1999: 7). This research required participants to have some background knowledge of China and accordingly "qualitative sampling" (Kuzel, 1992) instead of "statistical representativeness" was crucial to developing a structured sample. A well-designed focus group encourages participants to exchange viewpoints, delivering a balance between a structured meeting and a conversation (Kitzinger and Barbour, 1999; Agar and MacDonald, 1995). The selection of participants, the size of the group, and the organisation of participants into groups is arranged to maximise the participation of focus group members. Focus groups offer a more "natural environment" versus individual interviews, since, as in real life, participants influence and are influenced by others (Krueger and Casey, 2000: 11). Participants were also chosen based on the "most likely" principle (Flyvbjerg, 2006; Wu and Wall, 2019a), and included only those with sufficient knowledge of China and experience of the Chinese Dream as public diplomacy. Their UK residential status also ensured freedom of speech without censorship or retribution.

We applied a thematic analysis to focus group transcripts to identify pertinent themes. Five organising themes emerged from the contexts of economy, politics, culture, branding, and the Chinese identity. In this article, we focus on two of them - branding and the Chinese identity. 
Under the branding theme, we developed three further basic themes (codes) comprising the comparison between the American Dream and the Chinese Dream; successful practices of branding China in the Chinese Dream; and political controls as public diplomacy deficits. Similarly, under the Chinese identity theme, three basic themes (codes) were developed. They include ethnic Chinese are prescribed into the Chinese Dream; positive impacts of the association with the Chinese Dream; and negative impacts of the association with Mainland China (see Table 2).

Table 2. Thematic analysis of focus group interviews about the perception of and responses to the Chinese Dream branding campaigns

\begin{tabular}{|c|c|}
\hline Organising theme & Basic themes (codes) \\
\hline \multirow{3}{*}{$\begin{array}{l}\text { "The Chinese Dream is a good } \\
\text { concept ... Everybody has a dream" } \\
\text { Branding the Chinese rise as the } \\
\text { Chinese Dream is successful }\end{array}$} & $\begin{array}{l}\text { The American Dream vs. the Chinese } \\
\text { Dream }\end{array}$ \\
\hline & $\begin{array}{l}\text { Successful practices of branding } \\
\text { China in the Chinese Dream }\end{array}$ \\
\hline & $\begin{array}{l}\text { Political control as public diplomacy } \\
\text { deficits }\end{array}$ \\
\hline \multirow{3}{*}{$\begin{array}{l}\text { "We can see both sides of a coin" } \\
\text { The complex identity and cultural } \\
\text { affinity in Cultural China }\end{array}$} & $\begin{array}{l}\text { Ethnic Chinese are prescribed into the } \\
\text { Chinese Dream }\end{array}$ \\
\hline & $\begin{array}{l}\text { Positive impacts of the association } \\
\text { with the Chinese Dream }\end{array}$ \\
\hline & $\begin{array}{l}\text { Negative impacts of the association } \\
\text { with mainland China }\end{array}$ \\
\hline
\end{tabular}

In general, the Chinese Dream has been regarded as a successful branding practice that takes more control of the country internally, while conveying important international messages externally (Hurn, 2016). The Chinese Dream is regarded as a comprehensive strategy imbued with patriotic elements focusing on a particular type of "Chineseness," hence it triggers mixed and complex reactions among overseas audiences.

\section{Findings and Analysis}

When asked if they had heard of the Chinese Dream, all participants responded that they had, with ten of them answering that they were "familiar" with the concept from a variety of information sources.

Only three of the participants had first-hand experience of propaganda messaging in the shape of patriotic murals and songs during their visit to China, but all of the participants knew about the Chinese Dream from a mediated experience drawing on a sophisticated network of information. Media coverage from British and Chinese news outlets, including the BBC, The Times (of London), China Daily, People's Daily, and CCTV, were regarded as providing official albeit often diverging interpretations of the Chinese Dream. Digital and social media platforms including expat blogs, Weibo, and WeChat (a Chinese multi-purpose messaging and social media app), were used more widely, frequently, and intimately as a source of information. Person-to- 
person communication with family or friends in both countries constituted another information source. However, much of the interpersonal communication took place within the existing social media networks. The identification of information sources for the Chinese Dream reiterates the scholarly argument that media and communication technologies have built a transnational culture sphere within which the sense of belonging is a contested area (Sun, 2002; Yang, 2003; Wu, 2007; Wu and Wall 2019a; Wu and Wall 2019b).

\section{Branding the Chinese Rise as the Chinese Dream is Successful}

\section{The American Dream vs. the Chinese Dream}

Branding China's global rise within the concept of the Chinese Dream is regarded as a successful brand association (Anholt, 2010). As one respondent suggested, the Chinese Dream is "good" since "everybody has a dream” (B3).

Associations between the Chinese Dream and the American Dream were immediately noted by the non-Chinese Sinophile Group C, but not by the two ethnically Chinese groups. The brand association with the American Dream appealed to the non-Chinese group, who liked the idea that China might be supporting the development of individual success and wealth through its economic policies. C1, a female professional whose career is closely tied to China, said:

I'm familiar with the idea of the American dream, so when I heard about the Chinese dream, I thought, oh, this must be a Chinese version of that. The American dream of fulfilling individuals' aspirations was very much within a free-market economy ... So my perception of it was, well, China's undergone this amazing opening-up and economic growth ... Now we see a new sort of Chinese middle class ... these are the new rich and I would see these people as representing the Chinese dream. (C1)

C5, a US citizen residing in the UK, believed that the difference between the two dreams is that "collectivism" is important in China and "individualism" is more common in the American Dream. Also, governments are different in terms of the ways they direct personal lives:

The American Dream is very much about leaving me alone to do what I want so I can become as wealthy as possible on my own work. The point of the government is basically to ensure that we're all kind of on a level playing field and not killing each other. (C5)

Real-estate entrepreneur C2 believed that the promotion of the Chinese Dream demonstrates China's commitment to working with other countries. Such a branding practice may not be China's first choice, but one born out of necessity: "if you want to work on a global scale with partners, does China want to work together [with other countries] to educate each other to get the best global views?” C2 also pointed out that the Belt and Road Initiative ${ }^{1}$ - as part of the Chinese Dream - has been engaging people globally and bringing economic benefits: "This is a big investment scheme and I like the win-win approach in business that China talks about” (C2).

\footnotetext{
1 The Belt and Road Initiative (BRI, also known as One Belt, One Road Initiative) was introduced by President Xi Jinping in 2013 in projecting China's ambition to construct a global economic collaboration and international trade network. BRI comprises a land-based "Silk Road Economic Belt" and an oceangoing "Maritime Silk Road.” As of March 2020, 138 countries in Asia, Africa, Europe, and South America had signed a "BRI Memorandum of Understanding” with China. See the Xinhua Silk Road Information Service website, available at: https:/en.imsilkroad.com/.
} 
China's "reaching out" to the West was perceived positively by C1, who believed there is "great enrichment to be heard about [sic]" from China. She felt that the West's dominant worldview should be challenged, and that it needs to understand other countries. "Instead of reacting to it by saying 'I don't like it,' or 'I'm scared of it,' or 'I don't want to know,'” she claimed, if you "reach out, and you try to understand, it changes everything ... you're not stuck just in your own cultural bubble” (C1).

Although all respondents from Group C agreed that limited press freedom, human rights protections, and political transparency are apparent soft power deficits, the Chinese Dream communication softened them all to a degree, thus supporting nation-branding objectives to minimise unwanted stereotypes (Loo and Davies, 2006):

C3: ... as they were saying, the best-run countries are often run by benevolent dictators ...

C2: There's not that many of them around.

C3: You've only seen Singapore as an example. I mean, if the Chinese Dream is fulfilled as stated, that includes democracy; then, there's reasonable hope.

\section{Branding China with the Chinese Dream: successful practices}

While the positive reception of the Chinese Dream in Group C largely relies on a cultural affinity to the American Dream, the two Chinese groups demonstrate a deeper understanding of the changed perception of China and the Chinese in the West based on personal knowledge and experiences, thus demonstrating the co-creation of nation branding (Kavaratzis and Hatch, 2013). British-Chinese voluntary worker B1, originally from Hong Kong, believed that the Chinese Dream "is a strategic planning for the Chinese nation's future":

The purpose of the Chinese Dream is to project hope for everyone. If we don't have hope in our heart, we see China as weak and deprived, and nothing's good about China. The whole Chinese nation will lose its belief. The CPC is creating a vision for everyone - not only for people in China, but for anyone who have the Chinese blood in his/her body. The CPC believes that once the vision is there, it can guide everyone to work towards that goal.

This belief that the state/CPC is guiding an individuals' life choices for the collective good was echoed more strongly by Group A:

The Chinese Dream makes you aware that you don't have to sacrifice anything because you are part of the Chinese Dream. Your small dream is a part of the bigger dream ...(A1)

Other Group A members pointed out that by projecting the Chinese Dream, the CPC is "frank and honest" in acknowledging problems such as environmental pollution and corruption:

I'm surprised by Chinese media's reporting of the Chinese Dream. I didn't expect that the official media could be so blunt in addressing many issues from a critical point of view. (A2)

Some respondents from Group B believed the branding of the Chinese Dream is successful because it depoliticises China's ambition of global dominance and addresses individual advancement and aspiration. This common belief in self-cultivation and personal improvement has its roots in Confucianism and makes the Chinese Dream brand resonate with the wider ethnic Chinese community. 
B3: I rather like these three characters: Zhong, guo, meng [中国梦]. Because it's about a dream, you don't link it to politics, economy, or other objectives ... B4: It doesn't sound aggressive ...

B3: That's right. Everybody has a dream. It's good to have a dream.

Nevertheless, B4 - a dual citizen of Hong Kong and the UK - was cautious about the relationship between the individual and the state:

The translation of this concept is confusing. Sometimes it was translated into the Chinese Dream, but other times China's Dream. We wonder what exactly the meaning and connotations of the Zhongguo meng [sic]. How does the Chinese leadership define it?

\section{Branding the Chinese Dream: political control as public diplomacy deficit}

Focus group participants also identified the ineffectiveness of China's soft power branding. Political issues resulting from the one-party policy was cited by several Group C participants as the main soft power deficit:

C4: British and Chinese media all have their own sides, and they all have their own propaganda on issues. It's just unfortunately in China, the paper itself is owned by the state. It is state-run ... You're never going to get the alternative view or negative view or even an individual view of this whole idea. It's always going to be what the party is dictating or what the party saying in many respects.

C1: [Nodding in agreement] It's already tainted because it’s party politics.

C2 expressed similar views but concluded that it was too early to conclude that the branding of the Chinese Dream is a failure. Nevertheless, he imagined that it would be "interesting" to observe how the Chinese Dream values communicate to people in a democratic British context.

I cannot see any viewpoints that differ from [the official reporting of the Chinese Dream by] the Chinese media. It's all about positive energy and zero negative energy or voice of resistance. There's no press freedom. (C2)

Similar views were shared among the non-mainland ethnic Chinese Group B. The lack of press freedom and transparency was highlighted by B4, who disliked the idea that Facebook is blocked in China. B1 lamented the lack of alternative political viewpoints in the Chinese media, thereby not exhibiting the reciprocal commitment at the heart of successful nation branding (Wu, 2016). Group B members also expressed concerns about the expansion of China’s soft power:

B2: I feel [China's soft power] is too aggressive ... It's the extension of China's political influence. We need to prevent China's influence upon us ... B3: The invasion of China's soft power.

B2: That's right.

No such concerns regarding the political aspects of the Chinese Dream were apparent within Group A, made up of first-generation immigrants from mainland China. 


\section{The Complex Identity and Cultural Affinity in Cultural China}

\section{Ethnic Chinese are prescribed into the Chinese Dream}

Despite their different perceptions of Chinese politics, members from Group A and Group B used "we" as a collective pronoun when referring to ethnic Chinese as a distinct demographic in the British society. The use of the in-group pronoun "we” conveys an intention to create commonality, cohesion, and solidarity, yet it is simultaneously inclusive and exclusive (Pennycook, 1994). NonChinese people living in Britain therefore are referred to as waiguoren (外国人) or gweilo (鬼佬), showing a sense of alienation. Group C members, with close familial or professional connections to China, show a strong sense of adaptability in selectively identifying with Chinese values and believe that this gives them added insight, with C2 claiming that "all of us have an idea about China, and so we can see both sides.”

Ethnic Chinese are prescribed into the Chinese Dream - voluntarily or inadvertently Group A and Group B demonstrate that bicultural identity is about self-projection, but also about external perception (Miramontez, Benet-Martinez, and Nguyen, 2008), that is, how Chinese are perceived in mainstream British society. Accordingly, the "push" factors from host countries, including racism and stereotyping, often heighten feelings of alienation, isolation, and nostalgia for the lost homeland. This hunger for cultural identification unconsciously drives first generation Chinese immigrants in Group A towards the Chinese Dream, voluntarily or inadvertently.

Many waiguoren have never been to China and know nothing about the real China. ... Even if one of us has done anything they don't like, this small issue could be magnified as "all Chinese are like this.” (A2)

Race-based and ethnicity-based discriminations are felt by Group B members, too. Perceived physical differences (e.g., skin colour, hair texture, eye shape) and cultural practices (e.g., ancestor worship, lion dancing, Chinese herbal medicine) put ethnic Chinese in a marginalised position in the British society - they are simultaneously exoticized and trivialised. Guo (2009) concludes that such discrimination is based on "real and alleged differences [that] are claimed to be incompatible with the cultural and social fabric of the traditional” Western society. B1 used the phrase "the Chinese face" when expressing her sense of isolation as a result of which British Chinese communities are "pushed” into associations with the Chinese state:

When other people see us, they don't know if we are third generation or fourth generation immigrants? Or students from mainland China? Or from Japan? Or from Malaysia? Or from other Asian countries? They see us and assume that we are Chinese ... It's not an easy life for us as ethnic minorities. If China is doing well, we would receive more respect and less challenges. (B1)

Despite the previous disagreement with Chinese politics, a cultural affinity intensified by the use of global Chinese-language media (in particular entertainment TV shows) brought Group B close to the culture of China.

Most [of us] haven't lived in China. ... We are growing further and further from the "mother culture.” ... There's the soft side of the Chinese Dream. That TV show Sing! China is very popular overseas. That is the execution of the Chinese Dream. (B3) 
Digitalisation has transformed global communications and created a "home" media and cultural environment for the diaspora. As Sun (2002) argues, Chinese-language media usage among diaspora contributes to a "global Chinese village" and reshapes Chinese transnational imagination. Language maintenance within the British Chinese community functions as a "pull" factor and exposes the community to cultural products (as well as ideologies embedded in them) produced in Mandarin or other Chinese dialects.

\section{Positive impact of association with the Chinese Dream}

Being associated with the Chinese Dream was regarded as positive by Group A participants. Predominantly, the group believed that economic prosperity and cultural appeals are more effective than political slogans in drawing people closer to China:

I saw progress and development in China, which boosts up the confidence in overseas Chinese. ... We see more and more Chinese students and Chinese delegations in the UK, and more and more communication in the areas of economic and cultural exchanges. (A3)

A4 emphasises the importance of culture in building connections between generations and empathy between ethnic communities and wider British society:

My children would never ask me about the Chinese Dream, but they are interested in the Chinese culture. ... More and more of my British friends want to know about China and the Chinese culture. I feel that the culture is easier to be accepted than big external propaganda slogans. (A4)

China's economic development and political progress was also observed by Group C. C3 praised the soaring development in city infrastructure and C4 recalled living in China during the 2003 SARS crisis, adding that China has improved in terms of information transparency, public health, and environmental protection.

It is evident that the benefits of associations with the Chinese Dream seem largely dependent on an individual's profession. Those working in translation, education, or international trade detect a more positive influence than, for example, medical doctors. A5, a PhD degree holder working in the UK, said that the close UK-China collaboration "increased my employability." Similar views were expressed by other Groups A and B members:

Some small businesses see opportunities in the One Belt, One Road initiative. ... Some people even do not want to accept the fact that Chinese economy is powerful, they subconsciously know that China offers them opportunities. (B5)

The EU is no longer reliable, and the UK needs an external force to spur [its economy]. A series of bilateral activities show that China and the UK have been working closely together. My business ... has been getting better and better since 2012 [and] we have been offering services to official delegation visits, business cooperation, and cultural exchanges. (A1)

\section{Negative impact of association with mainland China}

Although China's economic strength was regarded as positive, it casts a negative impact on the perception of Chinese in the UK. A1, for example, commented that the extravagant lifestyles of 
some wealthy Chinese wrongly suggest that all Chinese are "rich and arrogant.” B3, a firstgeneration immigrant from Taiwan, asserted that news coverage of "rich Chinese" makes ordinary Chinese living overseas targets for "robbery and theft" (B3).

China's "soft power deficits," such as the political issues emanating from the one-party system, were discussed by Group B in particular as impacting negatively on their personal lives. B1, originally from Hong Kong, was concerned about the political situation in Hong Kong and consequent conflictual viewpoints among members of the local Chinese community. She blamed the "wall" (that is, the "Great Firewall of China" ${ }^{2}$ ) for creating political conflicts and tensions:

There are differences between the inside and outside. The wall created that obviously. ... I have never been to a Chinese university, but I believe that if they urge the students to learn about politics every day, then it is brainwashing. (B1)

But the most scathing criticism came from B3 - originally from Taiwan - who argued that the Confucius Institute aims to extend political control in the guise of cultural communication, leading to a misrepresentation of Chinese culture that only invites criticism and resistance. B2 and B1 interjected with their support:

B3: Germany has been resisting the Confucius Institute.

B2: So has the US.

B3: Their intention is to force them [the Confucius Institute] to leave.

B2: Because they felt that the Confucius Institutes are extensions of Chinese politics. Otherwise, why did they spend so much money on it?

B3: In the running of the Confucius Institute, it is supposed to be that a mainland Chinese university works with an overseas university. But the control is in China? The local teachers have no way to control. ... In my view, the Chinese Dream proposed by Xi Jinping does not only mean to unite mainland China; it also aims to control Chinese overseas. And it does not stop there, his ambition is to control the whole world. It serves his personal interest. I noted that recently $\mathrm{Xi}$ has changed the regulations on his presidential term of office. Isn't it changing his role back to the old emperor? He even changed the Constitution. China has many welfare problems. For example, food security, air pollution, water pollution ... These are the important issues. How could you ignore these home issues while aiming to influence the external ... B1: It's like a sick person - even the organs are failing but still put on a pretty face with beautiful makeup. To maintain that "face," there're prices paid.

Such statements offer further insights into the conflicted perspectives towards China's branding projects within the diverse British Chinese community, rooted in the complex political relations between China and other political entities in cultural China. As Rawnsley (2012, 2014) observes, Taiwan's political values appeal to the liberal-democratic West, yet its lack of formal diplomatic relations with major global powers constrains its exercise of soft power. China, despite its lack of democratic value, possesses and exercises more soft power capital due to the legitimacy built upon international recognition. Constrained by the lack of political recognition in the global community, Taiwan has competed against China for the legitimacy of representing authentic Chinese culture. It is evident that this politically driven endeavour has shaped Taiwanese immigrants' resistance to the Chinese Dream branding.

\footnotetext{
2 The Great Firewall of China refers to a set of legislative measures and technological tools used by the Chinese government in blocking access to foreign websites and apps in China.
} 


\section{Conclusion}

This article has appraised the reception of the Chinese Dream branding as perceived by selected demographics representing different subgroups in "cultural China” (Tu, 1994), thus responding to the call for more evaluation into the effectiveness of nation branding (Hassan and Mahrous 2019, He, et al. 2020). In analysing the themes generated from the focus groups, we synthesise the following key points in answer to our research questions.

Firstly, the reception of the Chinese Dream as nation branding is largely successful thanks to the cultural affinity maintained in cultural China. However, the interpretation of the Chinese Dream narrative is anything but unanimous. Our research participants responded positively to the use of "dream" and "culture" in soft power communication, indicating that cultural China might engage and promote China's brand values through a sense of belonging and the kind of reciprocal nation-branding commitment as conceptualised by $\mathrm{Wu}$ (2016). On the other hand, the interpretation of the Chinese Dream varied across the groups in our study. Our findings resonate to some degree with the argument that first-generation immigrants from mainland China benefit more from China's increasing strength and show a stronger emotional bond with, and political endorsement of, their "home" country (Nyíri, 1999, 2001). By contrast, non-mainland ethnic Chinese identify with the economic and cultural values to a certain degree, but express resistance to the Chinese Dream's political values. In particular, participants with familial, emotional, and cultural attachments to Hong Kong and Taiwan show various levels of resistance to the Chinese Dream concept. Members from the non-Chinese groups uphold the mainstream sociocultural values of British society, while demonstrating both endorsement and vigilance towards the objectives in the Chinese Dream branding. In sum, the Chinese Dream as public diplomacy builds empathy with the intended overseas audiences, but the reception of this nation branding exercise is characterised by contradiction, complexity, and conflicting perspectives.

Secondly, our analysis of nation branding strategies in relation to the changing Chinese identity is based upon the understanding that these strategies are about self-projection as well as external perception. Our original approach assesses nation branding within the theoretical framework of cultural China (Tu, 1994 [1991]). We extended Tu's articulation of the second symbolic universe of cultural China (Chinese diaspora in the UK) and drew data from the third symbolic universe (the cultural sphere consisting of non-Chinese professional writing and activities related to China). We argue that Chinese identity, has undergone profound transformation due to China's rise as a global power. Different subgroups within "cultural China" experience different impacts resulting from China's rise.

Positive impacts of China's rise are closely connected to the sociopolitical status of the ethnic Chinese diaspora in the UK. Various forms of racial discrimination based on physical or alleged differences between ethnic Chinese and mainstream society cause alienation and estrangement among ethnic Chinese, pushing them towards China's nation-branding projects for cultural identification. On the other hand, "pull” factors such as language maintenance, cultural affinity, and economic opportunities further enhance the attractiveness of the Chinese Dream brand and have potential to improve immigrants' social status in host societies. Torn between push and pull, our data confirms that Chinese immigrants are often "positioned uneasily in relation to the nation-building projects of both the country of origin and the destination" (Sun, 2006: 12). Negative impacts of China's rise on Chinese identity are centred around conflictual political interests among subgroups within cultural China. As we observe, the Chinese Dream as nation branding divides opinion when it focuses on political ideology. The findings highlight the incongruency of values or even competing interests among subgroups in endorsing certain nation branding projects while resisting others. The "practical arrangement of statesmanship" (Rawnsley, 2014: 173) grants the CPC-led China state soft power capital, but this precondition does not remove agency from other competing actors such as Taiwan. The escalating military and political 
tensions between China and other actors (in particular, Taiwan and Hong Kong) will inevitably lead to intensified nation branding competition.

Finally, the data shows that nation-branding efficiency largely depends on accessible global media and communications. Digital communication technologies have created a "global Chinese village" (Sun, 2002) and have facilitated the dissemination of cultural values in nation branding orchestrated by China. The respondents' knowledge of the Chinese Dream comes from a variety of sources including Chinese and British media reporting, person-to-person communication via digital messaging, and a range of commercial or citizen media on social media platforms including expat blogs, Weibo, and WeChat. Ethnic Chinese respondents also use Chinese-language entertainment programmes to maintain linguistic and cultural affinity. This non-official messaging facilitates the dissemination of Chinese cultural values via a symbolic interactionist process (Zhang, 2006) in which nation states and other actors participate in continuous meaning-making and negotiation with others. The digital environment also enables the possibility of co-creation by relevant stakeholders (Kavaratzis and Hatch, 2013). Nevertheless, the cultural communication's co-creation potential in Chinese Dream branding is not yet fully realised. If overseas audiences are to engage in China's national image management, then it is important that they can relate to the brand and the foci of its messages, aligning with the supranational cultures existing outside the geographic state borders (Yang, 2015).

Despite its limited empirical data and restricted sampling, this study has provided some significant insights. Further research will need to include a larger sample size from different parts of the UK and other parts of the world. Since completing this article, the world has witnessed the outbreak of the Covid-19 pandemic, the passing of the National Security Law in Hong Kong, and the escalation of cross-Taiwan Straits tensions. Cultural China will continue to be a tenet in any future research around Chinese nation branding projects (such as mask diplomacy and vaccine diplomacy), but it cannot be analysed without taking into account the political changes in the People's Republic of China, Greater China, and worldwide.

\section{References}

Adamson, Sue, Bankole Cole, Gary Craig, Basharat Hussain, Luana Smith, Ian Law, Carmen Lau, Chak-Kwan Chan, and Tom Cheung (2009), “Hidden From Public View?” Available at: https://essl.leeds.ac.uk/download/downloads/id/205/m'in_quan_finished_report.pdf (accessed 09.07.2020).

Agar, Michael, and James MacDonald (1995), “Focus Groups and Ethnography," Human Organization: Journal of the Society for Applied Anthropology 54 (1): 78-86.

Anholt, Simon (2002), “Nation Branding: A Continuing Theme,” Journal of Brand Management 10 (1): 59-60.

— - - (2007), "Competitive Identity: A New Model for the Brand Management of Nations, Cities and Regions," Policy and Practice: A Developmental Education Review 4: 3-13.

_ _ - (2010), “Definitions of Place Branding - Working Towards a Resolution,” Place Branding and Public Diplomacy 6 (1): 1-10.

Barr, Michael (2012), “National Branding as Nation Building: China’s Image Campaign,” East Asia 29: 81-94.

Benton, Gregor, and Edmund Terence Gomes (2011), The Chinese in Britain, 1800-Present: Economy, Transnationalism, Identity, Basingstoke: Palgrave Macmillan. 
Brady, Anne-Marie (2008), Marketing Dictatorship: Propaganda and Thought Work in Contemporary China, Plymouth: Rowman and Littlefield.

British Chamber of Commerce in China (2020), "British Business in China: Position Paper 2020," available at: https://www.britishchamber.cn/wp-content/uploads/2020/06/ENPOSITION-PAPER-2020-FINAL.pdf (accessed 09.07.2020).

Calmes, Jackie, and Steven Lee Myers (2013), “Obama and Xi Tackle Cybersecurity as Talks Begin in California,” New York Times, June 8.

Chang, Tsan-Kuo, and Fen Lin (2014), "From Propaganda to Public Diplomacy: Assessing China’s International Practice and Its Image, 1950-2009,” Public Relations Review 40 (3): 450-458.

Chen, Ni (2011), “The Evolving Chinese Government Spokesperson System,” in Jian Wang, ed., Soft Power in China: Public Diplomacy through Communication, 73-94, New York: Palgrave MacMillian.

China Daily (2014), “Seven Steps Toward the Chinese Dream," available at: http://www.chinadaily.com.cn/china/2014npcandcppcc/201403/05/content 17323054.htm (accessed 20.08.2014).

China International Culture Communication Centre (n.d.), “About the Centre,” available at: http://www.ciccc.org.cn/about/intro/ (accessed 09.07.2020).

CPC Central External Propaganda Research Office (1998), Duiwai xuanchuan zhongguo lunwenji (Collected Papers on External Propaganda), Beijing: Wuzhou chuanbo chubanshe.

Cull, Nicholas (2008), "The Public Diplomacy of the Modern Olympic Games and China's Soft Power Strategy,” in Price Monroe and Daniel Dayan, eds., Owning the Olympics: Narratives of the New China, 117-144, Ann Arbor: The University of Michigan Press.

Dayan, Daniel (1998), “Particularistic Media and Diasporic Communications”, in Tamar Liebes, James Curran, and Elihu Katz, eds., Media, Ritual and Identity, 103-113, London: Routledge.

d'Hooghe, Ingrid (2005), “Public Diplomacy in the People’s Republic of China,” in Jan Melissen, ed., The New Public Diplomacy: Soft Power in International Relations, 88-105, London: Palgrave Macmillian.

Ding, Sheng (2015), "Engaging Diaspora via Charm Offensive and Indegenised Communication: An Analysis of China's Diaspora Engagement Policies in the Xi Era,” Politics 35 (3/4): 230-244.

_ _ _ (2007), "Digital Diasporas and National Images Building: a New Perspective on Chinese Diaspora Study in the Age of China's Rise," Pacific Affairs 80 (4): 627-648.

Flyvbjerg, Bent (2006), "Five Misunderstandings About Case-Study Research,” Qualitative Inquiry 12 (2): 219-245.

Geis, John P., and Blaine Holt (2009), “'Harmonious Society’: Rise of the New China,” Strategic Studies Quarterly 3 (4): 75-94.

Gertner, David (2011), “Unfolding and Configuring Two Decades of Research and Publications on Place Marketing and Place Branding,” Place Branding and Public Diplomacy 7 (2): 91-106.

Gross, Andrew C., Poor Jozsef, Sipos Zoltan, and Solymossy Emeric (2009), "The Multiple Mandates of National Park Systems,” Place Branding and Public Diplomacy 5 (4): 276289. 
Guo, Shibao (2009), "Difference, Deficiency, and Devaluation: Tracing the Roots of Nonrecognition of Foreign Credentials for Immigrant Professionals in Canada," Canadian Journal for the Study of Adult Education 22 (1): 37-52.

Hassan, Salah, and Abeer A. Mahrous (2019), "Nation Branding: The Strategic Imperative for Sustainable Market Competitiveness," Journal of Humanities and Applied Social Sciences 1 (2): 146-158.

He, Lan, Rongdang Wang, and Mingshan Jiang (2020), "Evaluating the Effectiveness of China's Nation Branding with Data from Social Media," Global Media and China 5 (1): 3-21.

Hurn, Brian J. (2016), “The Role of Cultural Diplomacy in Nation Branding,” Industrial and Commercial Training 48 (2): 80-85.

Ji, Shuoming, and Donghua Zhou (2010), Zhongguo xinzheng (China's New Policy), Beijing: Zhongguo youyi.

Jones, Thomas, Shin Nagata, Monta Nkajima, and Kenichiro Masuyama (2009), "Prefectural Branding in Japan - Tourism, National Parks and the Shinshu Brand,” Place Branding and Public Diplomacy 5 (3): 192-201.

Kavaratzis, Mihalis, and Mary Jo Hatch (2013), "The Dynamics of Place Brands: An IdentityBased Approach to Place Branding Theory,” Marketing Theory 13 (1): 69-86.

Kemp, Elyria, Carla Y. Childers, and Kim H. Williams (2012), "Place Branding: Creating SelfAdvocacy Connections and Brand Advocacy," Journal of Product and Brand Management 21 (7): 508-515.

Kenez, Peter (1985), The Birth of the Propaganda State: Soviet Methods of Mass Mobilization 1917-1929, Cambridge: Cambridge University Press.

Kitzinger, Jenny, and Rosaline S. Barbour (1999), "Introduction: The Challenge and Promise of Focus Groups,” in Rosaline S. Barbour and Jenny Kitzinger, eds., Developing Focus Group Research: Politics, Theory and Practice, 1-20, London: SAGE.

Krueger, Richard A., and Mary Anne Casey (2000), Focus Groups: A Practical Guide for Applied Research, Thousand Oaks, CA: SAGE.

Kuhn, Robert Lawrence (2014), "Structuring the Chinese Dream,” China Daily, available at http://usa.chinadaily.com.cn/opinion/2014-01/25/content_17257856.htm (accessed 09.07.2017).

Kurlantzick, Joshua (2007), Charm Offensive: How China's Soft Power is Transforming the World, London: Yale University Press.

Kuzel, A. (1992), "Sampling in Qualitative Inquiry,” in Benjamin Crabtree and William Miller, eds., Doing Qualitative Research, 31-44, Newbury Park, CA: SAGE.

Li, Mingjiang (2009), Soft Power: China's Emerging Strategy in International Politics, Lanham, MA: Lexington Books.

Lieberthal, Kenneth (2004), Governing China: From Revolution through Reform, London: W. W. Norton.

Liu, Hong (2005), “New Migrants and the Revival of Overseas Chinese Nationalism,” Journal of Contemporary China 14(43): 291-316.

Liu, Hong, and Els van Dongen (2016), “China's Diaspora Policies as a New Mode of Transational Governance,” Journal of Contemporary China 25 (102): 805-821.

Loo, Teresa, and Gary Davies (2006), "Branding China: The Ultimate Challenge in Reputation Management,” Corporate Reputation Review 9 (3): 198-210. 
Lynch, Daniel C. (1999), After the Propaganda State: Media, Politics, and "Thought Work" in Reformed China, Stanford: Stanford University Press.

Merkelsen, Henrik, and Rasmus Kjærgaard Rasmussen (2016), "Nation Branding as an Emerging Field - an Institutional Perspective,” Place Branding and Public Diplomacy 12 (2/3): 99-109.

Miles, Steven B. (2020), Chinese Diasporas: A Social History of Global Migration, Cambridge: Cambridge University Press.

Miramontez, Daniel R., Veronica Benet-Martinez, and Angela-Minhtu D. Nguyen (2008), "Bicultural Idenitty and Self/Group Personality Perceptions," Self and Identity 7 (4): 430-445.

Mok, Tze Ming, and Lucinda Platt (2020), “All Look the Same? Diversity of Labour Market Outcomes of Chinese Ethnic Group Populations in the UK," Journal of Ethnic and Migration Studies 46 (1): 87-107.

Nakano, Ryoko, and Yujie Zhu (2020), "Heritage as Soft Power: Japan and China in International Politics,” International Journal of Cultural Policy 26 (7): 869-881.

Nye, Joseph S. (2012), “China’s Soft Power Deficit,” Harvard Kennedy School Belfer Center for Science and International Affairs, available at: http://www.belfercenter.org/publication/chinas-soft-power-deficit (accessed 14.10.2015).

Nyíri, Pál (1999), New Chinese Migrants in Europe: The Case of the Chinese Community in Hungary, Aldershot: Ashgate.

— - _ (2001), "Expatriating is Patriotic? The Discourse on 'New Migrants' in the People's Republic of China and Identity Construction Among Recent Migrants from the PRC," Journal of Ethnic and Migration Studies 27 (4): 635-653.

ONS (Office for National Statistics) (2013), "2011 Census: Key Statistics and Quick Statistics for Local Authorities in the United Kingdom,” available at: https://www.ons.gov.uk/peoplepopulationandcommunity/populationandmigration/pop ulationestimates/bulletins/keystatisticsandquickstatisticsforlocalauthoritiesintheunited kingdom/2013-10-11 (accessed 11.10.2013)

Pang, Mary (1996), "Barriers Perceived by Young Chinese Adults to their Employment in Companies in the UK," The International Journal of Human Resource Management 7 (4): 891-904.

Pennycook, Alistair (1994), “The Politics of Pronouns,” ELT Journal 48 (2): 173-178.

Polumbaum, Judy (2011), "Itching the Scratches on our Minds: American College Students Read and re-evaluate China,” in Jian Wang, ed., Soft Power in China: Public Diplomacy through Communication, 181-198, New York: Palgrave MacMillan.

Rawnsley, Gary (2012), “Approaches to Soft Power and Public Diplomacy in China and Taiwan,” The Journal of International Communication 18 (2): 121-135.

- _ - (2014), “Taiwan's Soft Power and Public Diplomacy,” Journal of Current Chinese Affairs 43 (3): 161-174.

Rees, Sian (2020), Public Relations, Branding and Authenticity: Brand Communications in the Digital Age, Abingdon: Routledge.

Riley, Patricia (2014), "Media Diplomacy: Public Diplomacy in a New Global Media Environment," in Thomas A. Hollihan, ed., The Dispute Over the Diaoyu/Senkaku Islands, 231-244, New York: Palgrave MacMillan. 
Servaes, Jan (2012), "Soft Power and Public Diplomacy: The New Frontier for Public Relations and International Communication between the US and China," Public Relations Review 38 (5): 643-651.

Sun, Wanning (2002), Leaving China: Media, Migration and Transnational Imagination, Lanham, MA: Rowman and Littlefield.

_ _ _ (2006), "Introduction: Transnationalism and a Global Diasporic Chinese Mediasphere,” in Wanning Sun, ed., Media and the Chinese Diaspora: Community, Communications and Commerce, 1-25, Oxon: Routledge.

Tang, Lu, and Hongmei Li (2011), “Chinese Corporate Diplomacy: Huawei’s CSR Discourse in Africa," in Jian Wang, ed., Soft Power in China: Public Diplomacy through Communication, 95-116, New York: Palgrave MacMillan.

The British Association for Chinese Studies (2020), "Report on the Present State of China-Related Studies in the UK,” available at: http://bacsuk.org.uk/bacs-report-on-china-relatedstudies-in-the-uk (accessed 09.07.2020).

The State Council Information Office of the PRC (2015), "Full Text: China's Military Strategy,” State Council Information Office of the PRC, available at: http://eng.mod.gov.cn/Press/2015-05/26/content_4586805.htm (accessed 08.2019).

Tu, Wei-ming (1994 [1991]), “Cultural China: The Periphery as the Center,” in Wei-ming Tu, ed., The Living Tree: the Changing Meaning of Being Chinese Today, 1-34, Stanford: Stanford University Press.

UK Council for International Student Affairs (2019), “International Student Statistics: UK Higher Education,” available at: https://www.ukcisa.org.uk/Research-Policy/Statistics/International-student-statistics-UK-higher-education $\quad$ (accessed 12.12.2019).

Universities UK (2019, July), “International Facts and Figures 2019,” available at: https://www.universitiesuk.ac.uk/International/Documents/2019/International\%20facts \%20and\%20figures\%20slides.pdf (accessed 09.07.2020).

Wang, Zhaoguo, and Bocong Yuan (2020), "Harmonizing the Branding Strategy of World Natural Heritage in China: Visitors' Awareness of the Multiple Brands of Wulingyuan, Zhangjiajie,” Geoheritage 12 (41): n.p.

Wu, Linwan (2016), "Relationship Building in Nation Branding: The Central Role of Nation Brand Commitment," Place Branding and Public Diplomacy 13 (1): 65-80.

Wu, Yan (2007), "Blurring Boundaries in a 'Cyber-Greater China': Are Internet Bulletin Boards Constructing the Public Sphere in China?,” in Richard Butsch, ed., Media and Public Spheres, 210-222, London: Palgrave Macmillan.

Wu, Yan, Richard Thomas, and Yakun Yu (2021), "From External Propaganda to Mediated Public Diplomacy: The Construction of the Chinese Dream in President Xi Jinping's New Year Speeches,” in Paweł Surowiec and Ilan Manor, eds., Public Diplomacy and the Politics of Uncertainty, 29-55, Cham: Palgrave Macmillan.

Wu, Yan, and Matthew Wall (2019a), "Prosumers in a Digital Multiverse: An Investigation of How WeChat is Affecting Chinese Citizen Journalism,” Global Media and China 4 (1): 36-51.

— — - (2019b), "The Ties That Bind: How the Dominance of WeChat Combines with Guanxi to Inhibit and Constrain China," New Media and Society 21 (8): 1-20.

Xi, Jinping (2014), The Governance of China, Beijing: Beijing Foreign Languages Press. 
Yang, Fan (2015), Faked in China: Nation Branding, Counterfeit Culture and Globalization, Bloomington: Indiana University Press.

Yang, Guobin (2003), “The Internet and the Rise of a Transnational Chinese Cultural Sphere,” Media, Culture and Society 25 (4): 469-490.

Yang, Guobin, and Craig Calhoun (2007), "Media, Civil Society, and the Rise of a Green Public Sphere in China," China Information: Special Issue on Environmental Activism 21 (2): 211-236.

Yi, Yan, and Tsan-Kuo Chang (2012), "Institutionalizing Public Relations in China: A Sociological Analysis of the Chinese Premier's Press Conference,” Public Relations Review 38 (5): 711-722.

Zhang, Juyan (2006), "Public Diplomacy as Symbolic Interactions: A Case Study of Asian Tsunami Relief Campaigns,” Public Relations Review 32 (1): 26-32.

Zhang, Xiaoling (2021), “China's Internatjional Broadcasting: A Case Study of CCTV International,” in Jian Wang, ed., Soft Power in China: Public Diplomacy Through Communication, 57-72, New York: Palgrave Macmillan.

Zhao, Yuezhi (1998), Media Market and Democracy: Between the Party Line and the Bottom Line, Urbana and Chicago: University of Illinois Press. 